\title{
Progression of the load of waterborne and intestinal parasitic diseases in the State of Amazonas
}

\author{
Marilaine Martins s[1], Marcus Vinícius Guimarães Lacerda ${ }^{[1],[2],}$ \\ Wuelton Marcelo Monteiro[1],[2], Marco Antonio Saboia Moura ${ }^{[1]}$, \\ Eyde Cristianne Saraiva Santos ${ }^{[3]}$, Valéria Saraceni ${ }^{[1],[4]}$ \\ and Maria Graças Gomes Saraiva[1],[5]
}

[1]. Fundação de Medicina Tropical Doutor Heitor Vieira Dourado, Manaus, AM. [2]. Escola Superior de Ciências da Saúde, Universidade do Estado do Amazonas, Manaus, AM. [3]. Faculdade de Ciências Agrárias, Universidade Federal do Amazonas, Manaus, AM. [4]. Secretaria Municipal de Saúde do Rio de Janeiro, Rio de Janeiro, RJ. [5]. Coordenação de Medicina, Universidade Nilton Lins, Manaus, AM.

\begin{abstract}
In the State of Amazonas, Brazil, urban expansion together with precarious basic sanitation conditions and human settlement on river banks has contributed to the persistence of waterborne and intestinal parasitic diseases. Time series of the recorded cases of cholera, typhoid fever, hepatitis A and leptospirosis are described, using data from different levels of the surveillance systems. The sources for intestinal parasitosis prevalence data (non-compulsory reporting in Brazil) were Medical Literature Analysis and Retrieval System Online (MEDLINE), Literatura Latino-Americana (LILACS) and the annals of major scientific meetings. Relevant papers and abstracts in all languages were accessed by two independent reviewers. The references cited by each relevant paper were scrutinized to locate additional papers. Despite its initial dissemination across the entire State of Amazonas, cholera was controlled in 1998. The magnitude of typhoid fever has decreased; however, a pattern characterized by eventual outbreaks still remains. Leptospirosis is an increasing cause of concern in association with the annual floods. The overall prevalence of intestinal parasites is high regardless of the municipality and the characteristics of areas and populations. The incidence of hepatitis A has decreased over the past decade. A comparison of older and recent surveys shows that the prevalence of intestinal parasitic diseases has remained constant. The load of waterborne and intestinal parasitic diseases ranks high among the health problems present in the State of Amazonas. Interventions aiming at basic sanitation and vaccination for hepatitis A were formulated and implemented, but assessment of their effectiveness in the targeted populations is still needed.
\end{abstract}

Keywords: Cholera. Leptospirosis. Typhoid fever. Hepatitis A. Intestinal parasites. Amazonas.

\section{INTRODUCTION}

Bacteria, viruses and parasites can enter drinking water in many ways, for example, as a result of pollution of a catchment area by animal excreta, by seepage of contaminated water into water distribution systems, and from unhygienic handling of stored household water. Protecting source water from pollution is critical for the prevention of waterborne diseases. Households can avoid most disease through 'safe water' approaches, by drawing on a well-managed supply system, or by treating and safely storing water at home. These interventions are most effective when coupled with improved sanitation and hygiene (including food hygiene) to ensure that multiple pathways of disease transmission are prevented ${ }^{(1)}$.

Corresponding author: Dra. Marilaine Martins. Gerência de Parasitologia/ FMT-HVD. Av. Pedro Teixeira 25, Dom Pedro, 69040-000 Manaus, AM, Brasil. Phone: 5592 2127-3434

e-mail: marilaine@fmt.am.gov.br

Received 23 July 2014

Accepted 25 November 2014
In Brazil, the average indices of services of water supply and sewage collection provided to the total population in 2012 were $82.7 \%$ and $48.3 \%$, respectively, as estimated by the National Information System on Sanitation [Sistema Nacional de Informações sobre Saneamento (SNIS)]. Considering the urban population only, high average indices of water supply and sewage collection services ( $93.2 \%$ and $56.1 \%$, respectively) were observed at the national level. In Brazil, 10 million inhabitants (6.2\% of the Brazilian urban population) have no access to sewage collection services, and 74,800 inhabitants $(0.05 \%$ of the country's urban population) have no access to water supply services ${ }^{(2)}$. The same report by SNIS identified striking regional differences, as the worst performer is the northern area, in which $68.6 \%$ of the urban population have access to water supply services and only $11.9 \%$ have access to sewage collection.

Analysis of the impact of inadequate sewage systems on health indicators in 81 Brazilian municipalities found clear associations between precarious basic sanitation, poverty, and hospital admissions for diarrhea. Poor areas and suburbs of large cities are the most critical areas with respect to the need for sewage collection services and the rates and cost of hospital admissions for diarrhea; this situation is particularly serious 
in northern and northeastern Brazil. In the City of Manaus, for instance, $74.8 \%$ of hospital admissions for diarrhea were children up to and including the age of five, and a high rate of child mortality due to diarrhea occurs ${ }^{(3)}$. As a result of the advancement of the Manaus Free-Trade Zone economic model, this area has undergone dramatic demographic growth since the 1970s, but the growth has not been accompanied by systematic urban planning. Instead, precarious and improvised dwellings were built on the margins of bodies of water. Inadequate use of available urban land and lack of infrastructure for basic sanitation have resulted in the degradation of bodies of water and their surrounding areas, with consequent risk to the local population ${ }^{(4)}$.

The aim of the present study was to describe the historical progression of the load of waterborne and intestinal parasitic diseases in the State of Amazonas.

\section{METHODS}

\section{Geographic characterization}

The State of Amazonas is located in the western part of the North Region of Brazil (latitude $2^{\circ} 01^{\prime}$, longitude $73^{\circ} 48^{\prime}$ ) and comprises an area of $1,559,159.148 \mathrm{~km}^{2}$ that contains 62 municipalities. The estimated population of the state in 2010 was 3,483,985 inhabitants, $74.2 \%$ of whom live in urban zones and $25.8 \%$ of whom live in rural areas. Its vegetation cover is mainly a dense evergreen rain forest. Its climate is classified as equatorial super-humid, with rainfall over $2,000 \mathrm{~mm}$ per annum and average annual temperatures between $26^{\circ} \mathrm{C}$ and $28^{\circ} \mathrm{C}$. There is no clear distinction between dry and rainy seasons, and the temperature shows little variation throughout the state ${ }^{(5)}$.

The primary urban agglomerations in 60 of the 62 municipalities in the State of Amazonas are located at the margins of rivers. The only two exceptions are the municipalities of Presidente Figueiredo and Apuí, which were developed at the sides of federal highways. The water of the Solimões/Amazonas River and its right-margin tributaries is mostly muddy, exhibits high concentrations of suspended sediment, and gives rise to floodplains; its $\mathrm{pH}$ varies from 6 to 7.2. The water of the leftmargin tributaries is dark and more acid ( $\mathrm{pH}$ approximately 5), exhibits lower sediment concentration, and gives rise to beaches in the summer. The water is underused, being mainly destined for household consumption and non-consumptive use (navigation, recreation, fish farming and hydropower). There is a need for an increased availability of water and the optimization of water use in Amazonas because there are deficits in the public water supply to households, while the basic sanitation system is merely incipient, thus leading to the pollution of bodies of water ${ }^{(6)}$.

\section{Data source}

The present article describes time series of recorded cases of cholera, typhoid fever, hepatitis A, and leptospirosis occurring in the State of Amazonas. These diseases are included in the Brazilian List of Diseases Subject to Compulsory Notification ${ }^{(7)}$. Data from different levels of the information systems were used to construct the time series.

Doctor Heitor Vieira Dourado Tropical Medicine Foundation [Fundação de Medicina Tropical Doutor Heitor Vieira Dourado
(FMT-HVD)] is a regional reference center for the diagnosis and treatment of tropical and infectious diseases as well as for the training of workers and the development of human resources. The Department of Epidemiology and Public Health [Departamento de Epidemiologia e Saúde Pública (DESP)] of FMT-HVD acts as a sentinel unit for diseases subject to compulsory notification or of regional interest and maintains epidemiological records on such conditions.

In the case of cholera, the data for the entire country as well as for the Northern region and the State of Amazonas were used. These data are derived from the records of notifications provided by the National Epidemiology Center [Centro Nacional de Epidemiologia (CENEPI)], Health Ministry, from 1991 to 1999. The map that depicts the geographic distribution of cholera per municipality in Amazonas was elaborated using ArcGIS 10.1 software based on records available at DESP/FMT-HVD, which acts as an epidemiological surveillance sentinel unit for the State Health Secretariat of Amazonas. Hydrological information was obtained from the National Water Agency of the Ministry of Environment.

The data on typhoid fever (1985-2012), leptospirosis (1985-2011), and hepatitis A (1991-2010) were collected from the records of DESP/FMT-HVD and the Notifiable Diseases Information System [Sistema Nacional de Agravos de Notificação (SINAN)].

A systematic review was conducted to find relevant information regarding surveys of intestinal parasite infections in the State of Amazonas. The sources for published data were MEDLINE (1947 to May 2014) and LILACS (1982 to May 2014). The following search strategy was used for both databases: (intestinal parasites).mp and (Amazonas OR Manaus).mp. Cross-sectional studies were included. The abstracts of publications were analyzed in detail by two independent reviewers, and publications were selected if they mentioned intestinal parasitosis prevalence. Disagreement between the two reviewers was solved through consensus. For the included studies, data were extracted on the date of publication, study site, number of patients, and prevalence by species. Potentially relevant papers in all languages were accessed to permit review of the full text. The references and reviews cited by each relevant paper were scrutinized to identify additional relevant papers. Unpublished studies were searched manually in the annals of the major Brazilian congresses. Inclusion and exclusion criteria similar to those used in the MEDLINE and LILACS searches were used in this search. If the abstract referred to a dissertation or thesis, more detailed information was presented here.

The data on amoebic liver abscess were gathered from the records of the FMT-HVD Board of Parasitology and Epidemiology for the 1992-2010 period.

\section{RESULTS AND DISCUSSION}

\section{Cholera}

The first occurrence of cholera in the State of Amazonas was recorded in May 1855. At that time, individuals originating from Belém in the State of Pará, where there was an ongoing cholera epidemic, spread the disease to other Amazonian areas when 
travelling by boat. In addition to records relating to Manaus, there are historical records on the occurrence of disease in some villages, such as Serpa (present-day Itacoatiara), Silves, and Vila Bela (present-day Parintins) $)^{(8)}$.

After almost 140 years with no recorded cases of cholera, cases of the disease were reported in Amazonas in 1991; this occurrence was a result of the spread of the seventh American epidemic ${ }^{(9)}$. Brazil was free of cholera until 1991, when the disease was re-introduced through the Amazonian forest at the Alto Solimões region and spread across the Brazilian Northern region along the Solimões/Amazonas River and its tributaries to reach the northeastern and southeastern areas via the main highways ${ }^{(10)}$. In Amazonas, the first cases were recorded in April 1991 at Benjamin Constant and Tabatinga municipalities, which are at international borders with Colombia and Peru. These cases were a result of the intense transmission pressure from Leticia, Colombia and Iquitos, Peru ${ }^{(11)}$.

A total of 5,810 cases of cholera were confirmed in the State of Amazonas during the period 1991 to 1998. These cases represented 3.6\% of the 163,099 cases in Brazil as a whole and $34.5 \%$ of the 16,827 cases in the Northern region. The largest number of cases per year were reported in 1991 (1,359 cases) and 1995 (1,452 cases). After 1995, the number of cases decreased gradually until 1998, when the last 17 cases of cholera were recorded in the state (Table 1). Although individuals of all ages were affected, the largest proportion of affected individuals $(59.3 \%)$ was 20 to 59 years of age. No cases of cholera were recorded in Amazonas after 1998. From 1991 to 1998, a total of 167 deaths by cholera were recorded in the State of Amazonas, corresponding to a fatality rate of $2.9 \%$. During this period, the average fatality rate from cholera was $1.2 \%$ nationally and $2.4 \%$ for the Amazon region. The highest annual fatality rate of $11.8 \%$ occurred in 1998, and the lowest annual fatality rate of $1.8 \%$ occurred in 1991 . The fact that the fatality rate increased during the same period (1996-1998) in which the number of cases decreased might be accounted for by a reduction in diagnostic suspicion, which may have permitted cases without accurate etiological diagnosis to end in death. Cases of cholera were recorded in 48 of the 62 municipalities in Amazonas and were distributed across the channels of the Solimões, Negro, Madeira, Purus, and Amazonas rivers. In Amazonas, autochthonous cases were recorded at the channels of the main rivers; in fact, the first cases occurred at Solimões River, from where cholera spread mainly through river transportation of individuals carrying Vibrio cholerae. Curiously, the number of autochthonous cases in Manaus and other municipalities of the Negro River channel was small, indicating that these areas were less vulnerable to the endemic disease. It has been suggested that the lower vulnerability of these areas was due to the low $\mathrm{pH}$ of the black waters, which might have to some extent limited bacterial dissemination. The important role FMT-HVD played as a reference unit for the treatment of patients was decisive in restricting the mortality of the cases referred to Manaus.

The rise of the Solimões River begins in November, and the river reaches its peak in June. It is worth noting that the highest incidence of cholera is associated with periods of ebb flows. The ebb begins in August, and the lowest tide occurs in October and lasts until January. During the dry period, the area and volume of the lakes become quite reduced, and the concentration of living beings and sediment increases. This period (October, November and December) is precisely the period in which the largest numbers of cases of cholera were recorded.

No cases of cholera have been reported in Brazil since 2005. The control of disease notwithstanding, precarious sanitation conditions make large areas vulnerable to cholera, particularly in the northern and northeastern regions. For that reason, the development of a system for surveillance of diarrheal diseases is important, as is the performance of studies on reintroduction of cholera through the immigration of carriers of Vibrio cholerae originating in countries in which transmission still occurs. In late 2010, Haitian immigrants began to arrive at remote river border crossings in the western Brazilian Amazon. Attracted by the prospect of work in Brazil's burgeoning economy, they entered Brazil through the border towns of Tabatinga (State of Amazonas) and Brasileia (State of Acre). Most of these

TABLE 1 - Cases of and deaths from cholera in Brazil. Brazilian Amazon and State of Amazonas, 1991-1998.

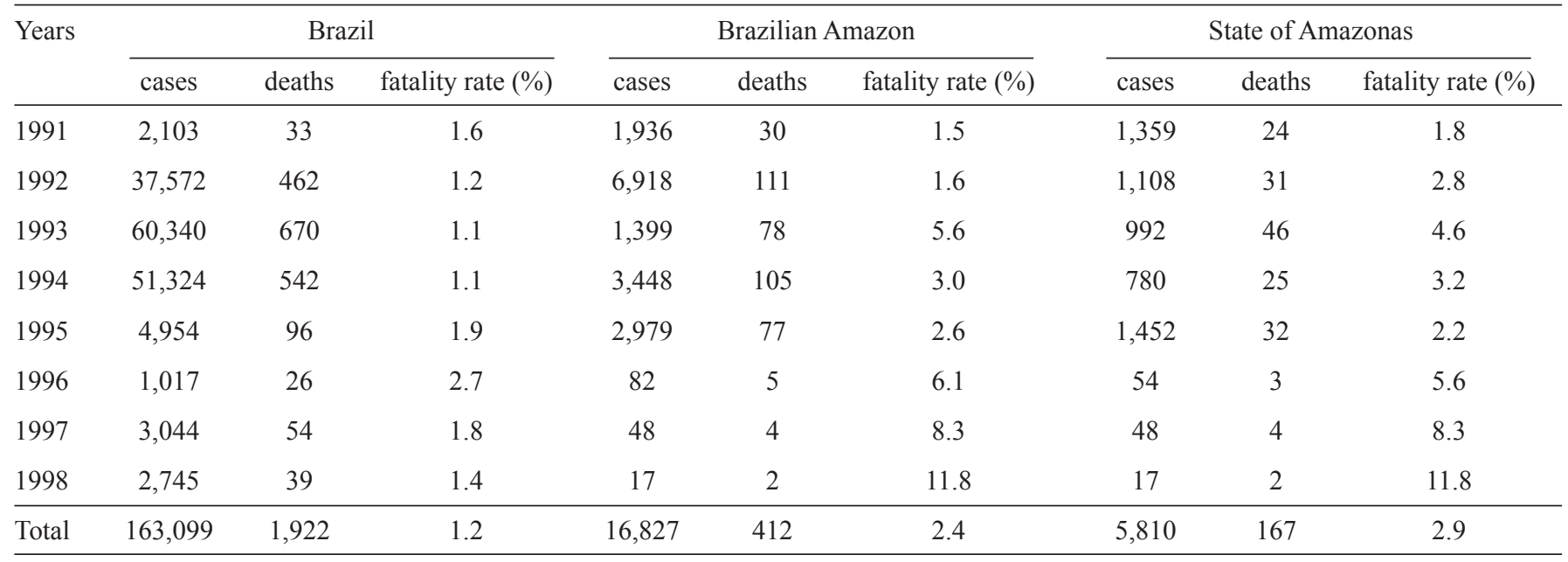


immigrants have made their way to Manaus. Because Haiti itself is facing a devastating cholera epidemic, it is necessary to assess the risk of reintroduction of cholera in susceptible areas in Brazil ${ }^{(12)}$.

A recent advance in the surveillance of this disease is the routine water surveillance performed in waters from the Tabatinga near the Peruvian/Colombian western border and in other regional rivers.

\section{Typhoid fever}

A total of 905 cases of typhoid fever were recorded in the State of Amazonas between 1985 and 2012. The largest number of cases, 77 , was reported in 1987 , followed by a decrease until 1990, when 16 cases were reported; the decreasing trend continued until 2003. During the period 2004 to 2012, the number of reported cases fluctuated, as shown in Figure 1A. Taking the full period into consideration, 145 cases occurred in individuals 15 to 19 years old, 373 in individuals age 35 to 49 years old, and 121 in individuals 50 to 64 years old. The pattern shown by the curve is compatible with those of diseases that appear in outbreaks. Two deaths were recorded during the studied period, one in 2000 and the other in 2003.

In Brazil, typhoid fever is endemic, with overlapping epidemic outbreaks, especially in the country's northern and northeastern areas, that depend on the living conditions of the local population ${ }^{(13)}$. More than half of the cases of typhoid fever in the country occur in the Brazilian Amazon due to its deficient sanitation conditions ${ }^{(14)}$. In the State of Amazonas, typhoid fever is endemic ${ }^{(15)(16)(17)}$. During the period 2004 to 2009, autochthonous cases were recorded in 23 neighborhoods in four districts in Manaus, with the greatest number of occurrences in the state's western and southern areas ${ }^{(16)(17)}$. Another 174 cases were reported in Manaus in 2010-2011 ${ }^{(18)}$; thus, the state capital exhibits the highest incidence of typhoid fever. The first case of Salmonella typhi in vitro and the first case of in vivo resistance to chloramphenicol in the Brazilian Amazon were reported in 2002, both occurring in a patient from Coari ${ }^{(19)}$. This suggests that one reason for the persistence of typhoid fever in the area might be the circulation of bacterial strains that are phenotypically resistant to antimicrobial agents.

One relevant factor that accounts for the persistence of the endemic pattern of disease in the area is the existence of asymptomatic $S$. typhi carriers, such as cooks on ships undergoing long journeys along the rivers in Amazonas. Such journeys are sometimes longer than 10 days, and they often lack appropriate treatment of the water consumed on board. Diagnosis of disease also poses a problem, especially in the interior of the state, due to the lack of qualified bacteriological laboratories. For that reason, the specific diagnosis of disease is reduced, and as a consequence, many suspected cases are treated empirically with antibiotic therapy without due notification. The results of the Widal test are not reliable for this population and thus must be interpreted cautiously.

\section{Leptospirosis}

There have been several reports of positive results of serologic tests for Leptospira in the Amazonian human population since the $1970 \mathrm{~s}^{(20)(21)(22)}$. One study conducted at that time in the State of Amazonas found that the risk of infection was greatest among sailors, miners, and workers in contact with sewage $^{(22)}$. In the interior of the State of Pará, the estimated serologic prevalence of leptospirosis in humans was $32.8 \%$ according to a microscopic agglutination test that is diagnostic for leptospirosis. The serovar bratislava was the most common (9\%), followed by the hardjo (6\%) and grippotyphosa (4.5\%) serovars ${ }^{(23)}$. In addition to the limited data on leptospirosis in the human population, there are records of infection of wild animals, rodents and marsupials in particular ${ }^{(21)(24)}$, as well as of domestic animals and cattle, with seroprevalence being as high as $97 \%$ among cattle in Uruará, State of Pará ${ }^{(23)}$.

Very little is known about the load and historical progression of the cases of leptospirosis recorded in the population of the State of Amazonas. A total of 835 cases and 71 deaths were recorded from 1985 to 2011 (31 cases per year on average), which corresponds to an average fatality rate of $2.6 \%$. The number of notifications increased during that period, peaking in 2011 (76 records). Figure 1B depicts the number of cases and deaths and the fatality rate during the aforementioned period. In the State of Amazonas, leptospirosis mostly affected male individuals 10 to 49 years of age. A total of 137 cases and 22 deaths (fatality rate: $12.7 \%$ ) were reported in Manaus between 2003 and 2007. During this period, the incidence of leptospirosis increased from 1.4/100,000 inhabitants in 2003 to $2.7 / 100,00$ inhabitants in $2006^{(25)}$. The increase in the number of cases of leptospirosis in the State of Amazonas was attributed to the Negro River floods, which resulted in the flooding of residential and commercial areas and exposure of the population to contamination by rodent excreta ${ }^{(26)}$.

The ecological structure of the Amazon is favorable to the dissemination of leptospirosis; the area displays an endemic pattern of disease that is likely a function of its tropical temperature and humidity and the poor hygienic habits of the population. Additionally, the abundant wild and synanthropic fauna, particularly rodents and marsupials, are potential reservoir hosts for Leptospira and might be a relevant factor contributing to the spread of leptospirosis in this area ${ }^{(21)(24)}$.

Because most cases of leptospirosis are either asymptomatic or manifest as acute undifferentiated febrile syndrome or acute neurological febrile syndrome (Leptospira-induced meningoencephalitis), often only the most severe cases of Weil syndrome are officially reported.

\section{Hepatitis A}

A total of 21,571 cases of hepatitis A were reported in the State of Amazonas between 1990 and 2012. The largest number of cases was reported in 2004; in that year, 2,249 cases were reported in Manaus and 2,578 in the remainder of the state. The number of cases began to decrease in 2005, only to eventually return to levels corresponding to those at the end of the ' $90 \mathrm{~s}$ (Figure 1C). The main prophylactic resource against hepatitis $A$ is vaccination ${ }^{(27)}$. The impact of the recent introduction of the hepatitis A vaccine in the basic immunization schedule for children in $2010^{(28)}$ has not yet been established in terms of efficiency of control of the disease. 

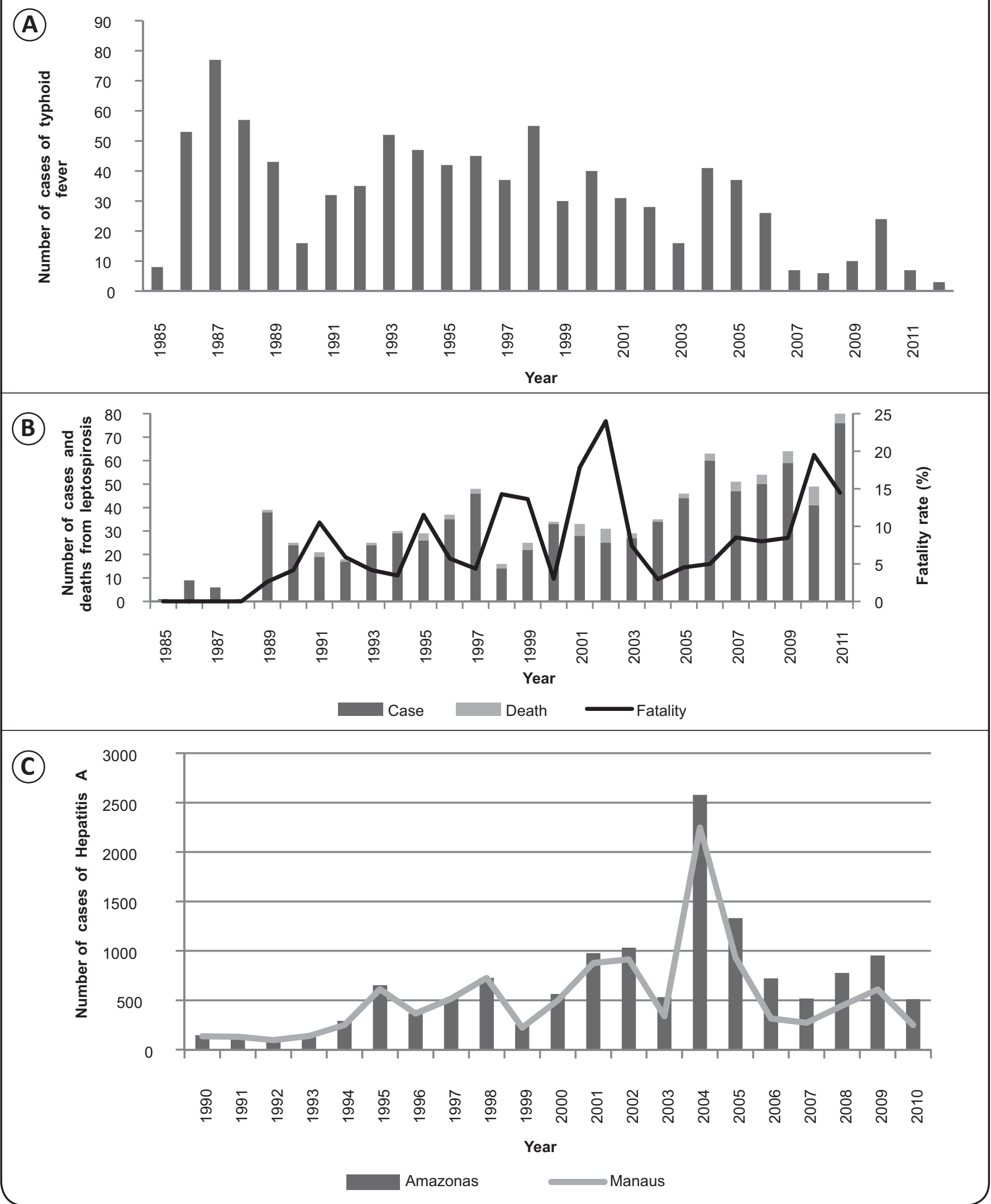

FIGURE 1 - A: Typhoid fever in the Amazon 1985 to 2012. B: Leptospirosis in humans in the Amazon from 1985 to 2011. C: Hepatitis A in the Amazon and Manaus from 1991 to 2010. 
Because the proportion of asymptomatic cases of hepatitis A is high, implementation of epidemiological surveillance actions is difficult and is usually limited to passive notification of cases. As a result, it is difficult to estimate the magnitude of the disease and to make appropriate and timely decisions regarding the required interventions ${ }^{(29)}$. The pattern of prevalence of anti- hepatitis A virus (HAV) total antibodies varies among Brazilian regions. Antibody prevalence is higher in the northern and midwestern regions, where it shows a pattern similar to that seen in underdeveloped regions, and lower in the southern and southeastern regions ${ }^{(30)}$. Although hepatitis A morbidity has declined progressively in Brazil as a whole, it remains high in the Amazon region. In Labrea, the prevalence of anti-HAV was $74.6 \%$, showing associations with age, the presence of outside toilets, history of hepatitis, family history of hepatitis, and the number of people in the family ${ }^{(31)}$. Other studies conducted in the Brazilian Amazon showed anti-HAV prevalences greater than $90 \%{ }^{(32)(33)}$.

Most water samples from the Amazon Basin tested positive (92\%) for HAV, with viral loads varying from 60 to 5,500 copies/L, depending on sanitary conditions and the degree of flooding. This observation emphasizes the serious public health problem posed by the presence of HAV in water samples in this area $^{(34)}$. Genotype 1A predominates in the Brazilian Amazon, similar to the situation in most South American countries ${ }^{(35)}$.

In Belém, 2 cases of leptospirosis and hepatitis A coinfection were reported in patients admitted to a local public hospital. This study highlights the importance of timely diagnosis of co-infection with leptospirosis and hepatitis A, which act synergistically to cause liver damage. It is necessary that health professionals be alert to this type of co-infection, especially in endemic areas that are homes to socioeconomically disadvantaged communities ${ }^{(36)}$. Likewise, the reporting of acute cases definitely underestimates the real burden of the disease because most cases of leptospirosis are asymptomatic or oligosymptomatic and because serological markers are typically requested only after a significant period of time.

\section{Intestinal parasitic diseases}

The MEDLINE search generated 17 papers related to intestinal parasitic diseases, and LILACS identified 17 papers. Eight papers were excluded because the prevalence of intestinal parasitic diseases was not the main focus of the study. Five articles were excluded because they reported data unrelated to the State of Amazonas. Four articles were repeated in the databases. After assessing the inclusion criteria, 17 original papers that included representative community surveys on intestinal parasites in the State of Amazonas were retrieved. An additional 22 reports were included based on the references of the articles searched from these sources. Nine abstracts were retrieved from the Annals of the Congress of the Brazilian Tropical Medicine Society. These 48 publications reported data for 17 municipalities from 1947 to 2014, with surveys performed in urban $(\mathrm{n}=31)$, rural $(\mathrm{n}=8)$, and riverine communities $(\mathrm{n}=4)$ and Amerindian villages $(\mathrm{n}=5)$ (Table 2 and Table 3) ${ }^{(37-84)}$.

The overall prevalence of intestinal parasites was very high regardless of the municipality or the characteristics of the areas and populations studied. Twenty-two parasite species were recorded; 11 of these were helminths, and 11 were protozoa. Of the 37 studies that reported the prevalence of at least one intestinal parasite, the prevalence rates were above $80 \%$ in 19 studies, $60 \%$ to $80 \%$ in 13 studies, and $40 \%$ to $60 \%$ in four studies. Comparison of older and more recent surveys did not show a reduction in the prevalence of intestinal parasitic diseases over time.

Ascaris lumbricoides exhibited the highest prevalence and was the predominant parasite found in 41 of the 48 studies. The prevalence rates for this parasite ranged from $2.8 \%$ in children aged 0 to 12 months in Manaus to $89.7 \%$ in Lábrea ${ }^{(69)}$. Trichiuris trichiura was the predominant parasite found in 5 studies; it was not found to affect children aged 0 to 12 months in Manaus ${ }^{(44)}$ or Waimiri-Atroari Indians in Presidente Figueiredo $^{(57)}$, but its prevalence in Codajás was $88.2 \%{ }^{(40)}$. The family Ancylostomatidae predominated in two surveys, with a prevalence of $95.9 \%$ among the Nadeb-Maku Indians of Santa Isabel do Rio Negro ${ }^{(48)}$. Other relatively frequent helminths were Strongyloides stercoralis, Enterobius vermicularis, and Hymenolepis nana. Fasciola hepatica was found in a single study conducted at Canutama, where its prevalence was $2 \%\left({ }^{(71)}\right.$. Schistosoma mansoni was found among immigrants from the northeastern area in two studies conducted in the urban area of Manaus, with $0.1 \%$ prevalence ${ }^{(38)(41)}$. Taenia $\mathrm{sp}$. was found in a single study conducted in the urban area of Manaus, with $0.1 \%$ prevalence ${ }^{(41)}$. The prevalence of Calodium hepaticum, a helminth parasite of dubious pathogenicity, in a study conducted at the Rio Pardo community in Presidente Figueiredo was $7 \%{ }^{(84)}$.

Of the pathogenic protozoa, Entamoeba histolytica/dispar exhibited the highest frequency, with a prevalence of greater than $50 \%$ in the Waimiri-Atroari Indian community at Presidente Figueiredo ${ }^{(57)}$ as well as in urban areas in the interior of the state, such as Novo Airão ${ }^{(59)}$, Iranduba ${ }^{(60)}$, Codajás ${ }^{(61)}$, and Envira ${ }^{(64)}$ municipalities, and in rural areas in Manaus municipality ${ }^{(62)(63)(70)}$. Extraintestinal amoebiasis is a serious complication of infection by E. histolytica/dispar, liver abscesses being its most common manifestation. There are no Brazilian nationwide statistics for the incidence of hepatic amoebiasis; however, the disease is known to be most frequent in the country's northern area ${ }^{(85)(86)(87)}$. A total of 442 cases of amoebic liver abscess were recorded among patients treated at FMT-HVD between 1992 and 2010, affecting mostly individuals 21 to 50 years of age (76.4\%) and male $(81.2 \%)$. Some deaths occurred due to spontaneous rupture of the abscesses into the abdominal cavity and secondary sepsis, the prognosis of which is indeed very poor. The number of cases of liver abscess with well-established cause began to decrease in 2004. It is worth noting that because the prevalence of intestinal amoebiasis did not decrease in that same period, as shown by the parasitological surveys cited in this study, it is believed that amoebic liver abscesses are underreported.

The prevalence of Giardia lamblia was approximately $30 \%$ in the urban areas of Manaus ${ }^{(4)(51)(82)}$, Novo Airão ${ }^{(59)}$ and Nova Olinda do Norte ${ }^{(46)}$. The prevalence of Blastocystis spp. was less than 5\% in Manaus ${ }^{(41)(62)(63)(70)(73)(82)}$, Novo Airão ${ }^{(59)}$ and Iranduba ${ }^{(60)}$, municipalities, but it was $13.4 \%$ among the Indians 
TABLE 2 - Systematic review of the prevalence of intestinal protozoa in the State of Amazonas, Brazil.

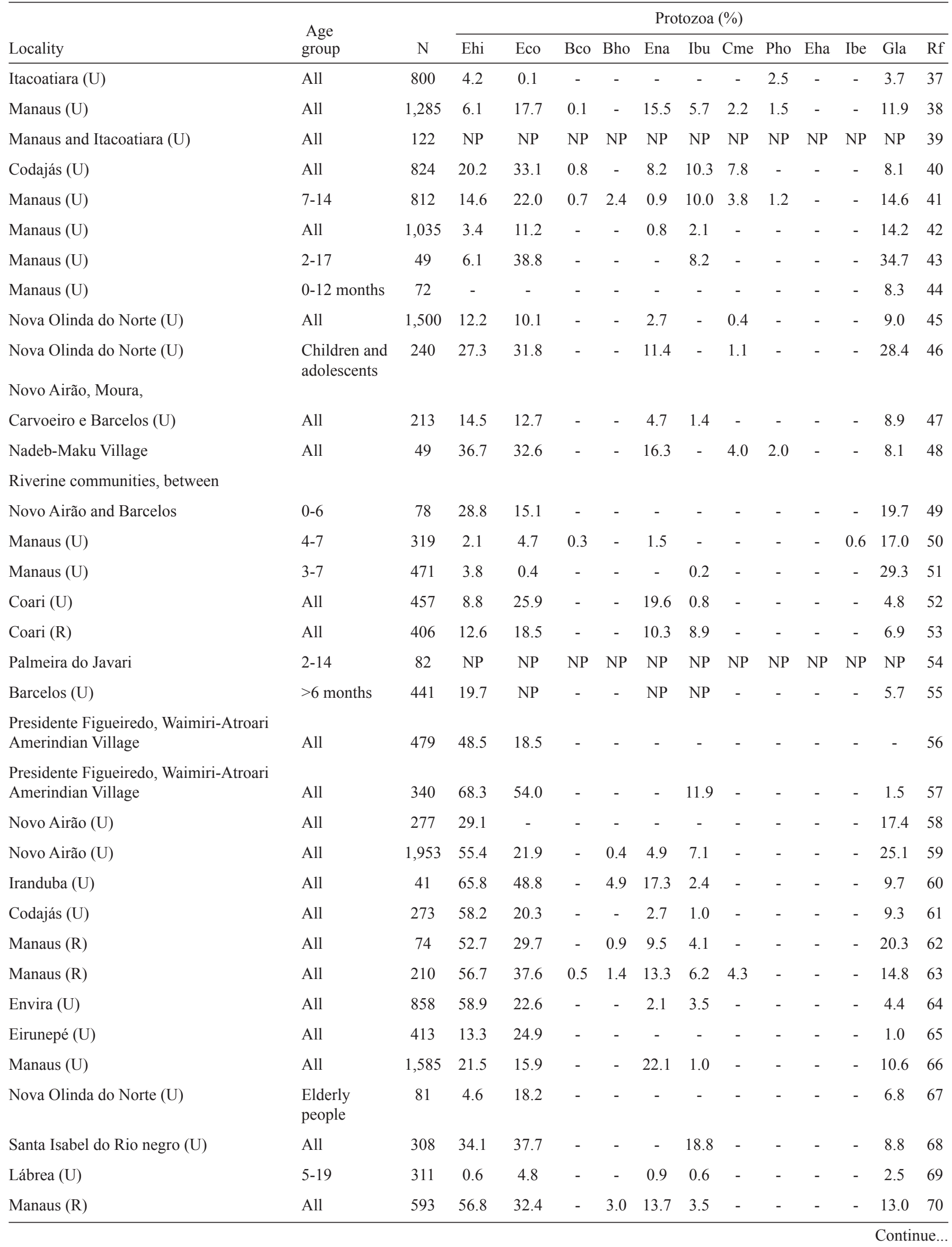


TABLE 2 - Continuation.

\begin{tabular}{|c|c|c|c|c|c|c|c|c|c|c|c|c|c|c|}
\hline Locality & $\begin{array}{l}\text { Age } \\
\text { group }\end{array}$ & $\mathrm{N}$ & \multicolumn{12}{|c|}{ Protozoa (\%) } \\
\hline Canutama (U) & All & 558 & 16.1 & 13.3 & - & - & 15.8 & 1.6 & 0.4 & - & - & - & 4.7 & 71 \\
\hline Iauaretê (Indigenous village) & All & 620 & 10.6 & 32.6 & - & 13.4 & 14.8 & 2.6 & 0.8 & - & 0.3 & - & 8.5 & 72 \\
\hline Manaus (U) & $0-10$ & 347 & 11.5 & 10.4 & - & - & 19.6 & 3.7 & - & - & - & - & 23.3 & 73 \\
\hline Coari (R) & $0-10$ & 211 & 14.0 & 11.0 & - & - & 1.0 & - & - & - & - & - & 4.4 & 75 \\
\hline Santa Isabel do Rio negro (U) & All & 450 & 31.0 & 37.0 & - & - & - & 4.2 & 2.1 & - & - & - & 8.3 & 76 \\
\hline Manaus (U) & $0-11$ & 451 & 13.7 & 10.2 & - & 1.1 & 17.9 & 3.1 & - & - & - & - & 21.5 & 77 \\
\hline Coari (R) & $0-15$ & 123 & 17.6 & 11.0 & - & - & 3.3 & 1.1 & - & - & - & - & 9.9 & 78 \\
\hline Manaus (U) & All & 400 & 20.8 & 19.8 & - & - & 19.8 & 4.3 & - & - & - & - & 10.3 & 81 \\
\hline Manaus (U) & All & 362 & 27.4 & 42.2 & 0.7 & 0.7 & 39.3 & 8.1 & - & - & - & - & 27.4 & 82 \\
\hline Coari (Riverine community) & $1-12$ & 65 & - & 9.2 & - & - & - & - & - & - & - & - & 5.5 & 83 \\
\hline Presidente Figueiredo (R) & All & 143 & 4.2 & NP & - & 43.4 & NP & NP & - & - & - & - & 10.5 & 84 \\
\hline
\end{tabular}

U: Urbane zone; R: Rural zone; Ehi: Entamoeba histolytica/dispar; Eco: Entamoeba coli; Bco: Balantidium coli; Bho: Blastocystis hominis; Ena: Endolimax nana; Ibu: Iodamoeba butschlii; Cme: Chilomastix mesnili; Pho: Pentatrichomonas hominis; Eha: Entamoeba hartmanni; Ibe: Isospora belli; Gla: Giardia lamblia. Rf: Reference; NP: data not presented.

of São Gabriel da Cachoeira municipality ${ }^{(72)}$ and $43.4 \%$ in the rural area of Presidente Figueiredo ${ }^{(84)}$. The prevalence of Balantidium coli ranged from $0.1 \%$ to $0.8 \%$ in six studies conducted at the Manaus $^{(38)}$ (41) (50) (63) (82) and Codajás ${ }^{(40)}$ municipalities. Isospora belli was found in a single study conducted at the urban area of Manaus, with a prevalence rate of $0.6 \%{ }^{(50)}$.

Entamoeba coli was the most frequently found commensal protozoan, followed by Endolimax nana and Iodamoeba butschlii. The prevalence of E. coli was above $40 \%$ in the Waimiri-Atroari village in Presidente Figueiredo ${ }^{(57)}$ and in Iranduba $^{(60)}$ and Manaus ${ }^{(82)}$ municipalities. Other commensal species included Chilomastix mesnili, Pentatrichomonas hominis and Entamoeba hartmanni. Although the high prevalences of these protozoan species do not represent a true risk to the population's health, they reflect the precariousness of the hygienic and sanitary conditions in the studied areas.

It is worth noting that the diagnostic methods used exhibited wide variation between studies and that many studies used the direct method only. Among the techniques for parasite concentration, spontaneous sedimentation was the most frequently used. This technique exhibits the highest sensitivity for dense parasite forms such as the eggs of the helminths Ascaris lumbricoides and Trichuris trichiura. For these reasons, it is believed that the prevalence of some parasites, particularly those belonging to the family Ancylostomatidae and protozoa as a whole, might be underestimated.
In general, over the last 30 years, the epidemiological transition seen at the reference center in Manaus, the FMT-HVD, indicates an increase in the amount of opportunistic pathogens such as Cryptosporidium spp., Isospora belli and microsporidia. This development may also be due to the emergence of the acquired immunodeficiency syndrome (AIDS) epidemic in this state.

\section{CONCLUDING REMARKS}

A number of strategies aiming at the control of waterborne and intestinal parasitic diseases were planned at the national and state levels. In 2011, the Ministry of Health established a list of endemic diseases that require strategic actions for their elimination as public health concerns or to achieve a dramatic reduction of their load. For one of the diseases on this list, geohelminthiasis $^{(88)}$, the Ministry of Health suggested the implementation of mass treatment of children five to 14 years of age in the municipalities with the highest prevalence rates.

In 2006, the government of the State of Amazonas launched the Social and Environmental Program for Manaus Igarapés [Programa Social e Ambiental dos Igarapés de Manaus (PROSAMIM)], the goal of which is to improve local environmental and health conditions through the establishment and rehabilitation of drainage and water supply systems, environmental recovery of floodplains and springs, and improvement of the dwelling conditions of the local population. It is worth noting that one of the subcomponents 
TABLE 3 - Systematic review of the prevalence of intestinal helminthes parasitic diseases in the State of Amazonas, Brazil.

\begin{tabular}{|c|c|c|c|c|c|c|c|c|c|c|c|c|c|c|}
\hline Locality & $\begin{array}{l}\text { Age } \\
\text { group }\end{array}$ & $\mathrm{N}$ & \multicolumn{12}{|c|}{ Helminthes $(\%)$} \\
\hline Itacoatiara (U) & All & 800 & 82.1 & 69.6 & 49.4 & 4.1 & 0.1 & 0.1 & - & - & - & - & - & 37 \\
\hline Manaus (U) & All & 1,285 & 31.0 & 17.2 & 24.2 & 2.1 & 0.1 & - & - & - & 0.1 & - & - & 38 \\
\hline Manaus and Itacoatiara (U) & All & 122 & 54.8 & 14.6 & 25.0 & NP & NP & NP & NP & NP & NP & NP & NP & 39 \\
\hline Manaus (U) & $7-14$ & 812 & 77.2 & 78.4 & 49.8 & 11.5 & 0.2 & 0.2 & - & - & 0.1 & 0.1 & - & 41 \\
\hline Manaus (U) & All & 1,035 & 55.8 & 72.1 & 51.1 & 9.3 & 0.9 & 0.2 & - & - & - & - & - & 42 \\
\hline Manaus (U) & $2-17$ & 49 & 73.5 & 89.8 & 71.4 & 12.2 & 8.2 & - & - & - & - & - & - & 43 \\
\hline Manaus (U) & $0-12$ months & 72 & 2.8 & - & 1.4 & - & - & - & - & - & - & - & - & 44 \\
\hline Novo Airão, Moura, Carvoeiro e & All & 213 & 54.5 & 52.1 & 40.4 & 2.3 & - & - & - & - & - & - & - & 47 \\
\hline \multicolumn{15}{|l|}{ Barcelos (U) } \\
\hline Nadeb-Maku Village & All & 49 & 61.2 & 67.3 & 95.9 & 12.2 & - & - & - & - & - & - & - & 48 \\
\hline Riverine communities, between & $0-6$ & 78 & 72.7 & 66.7 & 62.1 & 16.7 & - & - & - & - & - & - & - & 49 \\
\hline \multicolumn{15}{|l|}{ Novo Airão and Barcelos } \\
\hline Manaus (U) & $4-7$ & 319 & 22.3 & 17.3 & 0.9 & 0.3 & 0.6 & 0.9 & - & - & - & - & - & 50 \\
\hline Manaus (U) & $3-7$ & 471 & 47.8 & 66.6 & 8.0 & 1.0 & 1.4 & - & - & - & - & - & - & 51 \\
\hline $\begin{array}{l}\text { Presidente Figueiredo, Waimiri- } \\
\text { Atroari Amerindian Village }\end{array}$ & All & 340 & 56.7 & 3.5 & 14.0 & - & 6.5 & 0.1 & - & - & - & - & - & 57 \\
\hline Novo Airão (U) & All & 277 & 35.1 & 4.7 & 4.7 & 2.5 & 0.1 & - & - & - & - & - & - & 58 \\
\hline Novo Airão (U) & All & 1,953 & 69.4 & 15.1 & 17.4 & 1.9 & 3.6 & 1.1 & - & 0.1 & - & - & - & 59 \\
\hline Iranduba (U) & All & 41 & 75.6 & 34.1 & 46.3 & 2.4 & 4.9 & 0.9 & - & 0.3 & - & - & - & 60 \\
\hline Codajás (U) & All & 273 & 69.4 & 13.5 & 24.0 & 10.3 & 1.7 & 0.3 & - & 0.3 & - & - & - & 61 \\
\hline Manaus (R) & All & 74 & 54.1 & 9.5 & 8.1 & 2.3 & 1.4 & 0.2 & - & 0.2 & - & - & - & 62 \\
\hline Manaus (R) & All & 210 & 59.0 & 21.0 & 22.4 & 2.9 & 0.5 & 8.1 & - & 3.3 & - & - & - & 63 \\
\hline Envira (U) & All & 858 & 57.1 & 21.2 & 12.4 & 4.7 & 0.5 & 0.2 & - & 0.2 & - & - & - & 64 \\
\hline Eirunepé (U) & All & 413 & 35.6 & 18.6 & 9.9 & 1.0 & 0.5 & - & - & - & - & - & - & 65 \\
\hline Manaus (U) & All & 1,585 & 11.9 & 4.9 & 2.1 & 1.3 & - & - & - & - & - & - & - & 66 \\
\hline Nova Olinda do Norte (U) & Elderly people & 81 & 35.2 & 15.9 & 9.1 & 9.1 & 1.1 & - & - & - & - & - & - & 67 \\
\hline Santa Isabel do Rio negro (U) & All & 308 & 47.7 & 25.6 & 21.4 & - & - & - & - & - & - & - & - & 68 \\
\hline Lábrea (U) & $5-19$ & 311 & 89.7 & 64.3 & 51.7 & 10.6 & - & - & - & - & - & - & - & 69 \\
\hline Manaus (R) & All & 593 & 37.4 & 5.7 & 17.9 & 2.9 & 0.8 & 2.2 & - & - & - & - & - & 70 \\
\hline
\end{tabular}


TABLE 3 - Continuation.

\begin{tabular}{|c|c|c|c|c|c|c|c|c|c|c|c|c|c|c|}
\hline Locality & $\begin{array}{l}\text { Age } \\
\text { group }\end{array}$ & $\mathrm{N}$ & \multicolumn{12}{|c|}{ Helminthes $(\%)$} \\
\hline Canutama (U) & All & 558 & 37.6 & 10.0 & 14.7 & 4.5 & - & 1.1 & 2.0 & - & - & - & - & 71 \\
\hline Iauaretê (Indigenous village) & All & 620 & 64.8 & 4.7 & 5.0 & 1.3 & 1.0 & 5.3 & - & - & - & - & - & 72 \\
\hline Manaus (U) & $0-10$ & 347 & 14.1 & 4.6 & 1.4 & - & 2.3 & - & - & - & - & - & - & 73 \\
\hline Coari (R) & $0-10$ & 211 & 37.0 & 21.6 & 5.0 & 0.8 & 2.4 & 2.0 & - & 0.4 & - & - & - & 75 \\
\hline Santa Isabel do Rio negro (U) & All & 450 & 35.0 & 2.1 & - & - & - & - & - & - & - & - & - & 76 \\
\hline Manaus (U) & $0-11$ & 451 & 13.5 & 4.9 & 1.1 & 0.6 & 2.6 & - & - & - & - & - & - & 77 \\
\hline Coari (R) & $0-15$ & 123 & 68.1 & 41.8 & 17.6 & 8.8 & - & - & - & - & - & - & - & 78 \\
\hline Manaus (U) & All & 400 & 12.0 & 4.5 & 9.5 & 3.8 & 11.0 & 2.0 & - & - & - & - & - & 81 \\
\hline Manaus (U) & All & 362 & 70.0 & 17.5 & 7.5 & - & 2.5 & 22.5 & - & - & - & - & - & 82 \\
\hline Coari (Riverine community) & $1-12$ & 65 & 53.7 & 16.6 & 15.0 & - & - & - & - & - & - & - & - & 83 \\
\hline Presidente Figueiredo (R) & All & 143 & 14.0 & 9.8 & 25.9 & - & - & - & - & - & - & - & 7.0 & 84 \\
\hline
\end{tabular}

U: Urbane zone; R: Rural zone; Alu: Ascaris lumbricoides; Ttr: Trichuris trichiura; Hwo: Hookworms; Sst: Strongyloides stercoralis; Eve: Enterobius vermicularis; Hna: Hymenolepis nana; Fhe: Fasciola hepatica; Hdi: Hymenolepis diminuta; Sma: Schistosoma mansoni; Tsp: Taenia sp.; Che: Capilaria hepatica. Rf: Reference; NP: data not presented

of this program is devoted to investment in drinking water and sewage services for the resettled and remaining populations in the area of influence of the drainage basin. However, the present study found that such strategies did not result in significant improvement from a wider perspective. Nevertheless, assessment of the effectiveness of the interventions in the area targeted by the program has not yet been performed.

Unsafe water and inadequate sanitation and hygiene are significant contributors to the spread of diarrheal and other diseases in the State of Amazonas that eventually result in death. Perpetuation of the transmission cycle of waterborne and intestinal parasitic diseases is strongly facilitated by the environmental conditions of the Amazon region. The quality of water, whether used for drinking, domestic purposes, food production, or recreational purposes, has an important impact on health. Initiatives to manage the safety of water not only support public health but also often promote socioeconomic development and well-being ${ }^{(89)}$.In this context, there is an urgent need to focus attention on achieving sanitation in this state.

\section{ACKNOWLEDGMENTS}

The authors thank all the professionals in the epidemiological surveillance system of the State of Amazonas and most particularly those at the Surveillance Foundation of the State of Amazonas and the Doctor Heitor Vieira Dourado Tropical Medicine Foundation.

\section{CONFLICT OF INTEREST}

The authors declare that there is no conflict of interest.

\section{REFERENCES}

1. World Health Organization (Internet). Preventing waterborne disease. (Cited May 20). Available at: http://www.who.int/phe/ events/wha_66/flyer_wsh_water_borne_disease.pdf?ua=1

2. Ministério das Cidades (Internet). Diagnóstico dos Serviços de Água e Esgotos - 2012. (Cited May 20). Available at: http://www. snis.gov.br/PaginaCarrega.php?EWRErterterTERTer=103

3. Trata Brasil Saneamento e Saúde (Internet). Esgotamento sanitário inadequado e impactos na saúde da população: um diagnóstico da situação nos 81 municípios brasileiros com mais de 300 mil habitantes. (Cited May 20). Available at: http://www.tratabrasil.org. br/novo_site/cms/templates/trata_brasil/files/esgotamento.pdf

4. Governo do Estado do Amazonas (Internet). Programa Social e Ambiental dos Igarapés de Manaus (PROSAMIM): Estudo Prévio de Impacto Ambiental (Cited 2012 May 20). Available at: http:// prosamim.am.gov.br/wp-content/uploads/2012/05/estudo-impactoamb-prosamim1.pdf

5. Instituto Brasileiro de Geografia e Estatística (Internet). Amazonas (Cited May 20). Available at: http://www.ibge.gov.br/estadosat/ perfil.php?sigla $=$ am

6. Ministério do Meio Ambiente (Internet). Panorama da Qualidade das Águas Superficiais no Brasil (Cited 2012 May 20). Available at: 
http://pnqa.ana.gov.br/Publicao/PANORAMA\%20DA\%20 QUALIDADE\%20DAS\%20\%C3\%81GUAS.pdf.

7. Ministério da Saúde. Portaria $N^{\circ} 5$, de 21 de fevereiro de 2006 (Directive No. 5, February 21, 2006). Published in DOU no. 38, of February 22, 2006, Page 34, Section 1.

8. Rojas LI, Toledo LM. Espaço \& doença: um olhar sobre o Amazonas. Rio de Janeiro: Editora Fiocruz; 1998. p. 175.

9. Penna ML, Silva LP. Algumas considerações sobre a ocorrência de cólera no Brasil. Informe Epidemiológico do SUS 1992; 1:7-15.

10. Ministério da Saúde. Secretaria de Vigilância em Saúde. Cólera. Guia de Vigilância Epidemiológica. Caderno 5. $7^{\text {th }}$ ed. Brasília: Ministério da Saúde; 2010. p. 15-31.

11. Mujica OJ, Quick RE, Palacios AM, Beingolea L, Vargas R, Moreno D, et al. Epidemic Cholera in the Amazon: The Role of Produce in Disease Risk and Prevention. J Infect Dis 1994; 169:1381-1384.

12. Rawlinson T, Siqueira AM, Fontes G, Beltrão RPL, Monteiro WM, Martins M, et al. From Haiti to the Amazon: Public Health Issues Related to the Recent Immigration of Haitians to Brazil. PLOS Negl Trop Dis 2014; 8: e2685.

13. Ministério da Saúde. Secretaria de Vigilância em Saúde. Febre tifóide. Guia de Vigilância Epidemiológica. Caderno 5. $7^{\text {th }}$ ed. Brasília: Ministério da Saúde; 2010. p. 49-60.

14. Fundação Nacional de Saúde, Centro Nacional de Epidemiologia. Relatório de doenças emergentes e reemergentes no Brasil, Brasília: Ministério da Saúde; 1999/2000.

15. Saraiva MGG, Moura MAS, Carvalho DL, Mota CB, Queiroz JMT, Santos ECS, et al. Leptospirose no município de ManausAmazonas. Rev Soc Bras Med Trop 2009; 42:284.

16. Saraiva MGG, Moura MAS, Mota CB, Barbosa MGV, Nogueira GC, Santos ECS, et al. Febre tifóide: aspecto epidemiológico e bacteriológico com distribuição espacial. In: IV Simpósio Nacional de Geografia da Saúde. Uberlândia; 2009. 1380-1383.

17. Saraiva MGG, Barros TS, Monte RL, Moura MAS, Mendes MGS, Amorim RDS, et al. Febre tifóide: importante doença de veiculação hídrica no Amazonas. Rev Soc Bras Med Trop 2005; 38 : (supl I) 135.

18. Seabra DMR, Santos MC, Lopes EJS, Mota CB, Moura MAS, Nogueira GC, et al. Febre tifóide em Manaus, Amazonas: análise dos aspectos epidemiológicos, e conhecimentos e atitudes dos comerciantes de alimentos em áreas portuárias. In: II Congresso de Iniciação Científica da FMT-HVD. Manaus; 2012. p. 26.

19. Alecrim WD, Loureiro ACSP, Moraes RS, Monte RL, Lacerda MVG. Febre tifóide: Recaída por resistência antimicrobiana. Relato de caso. Rev Soc Bras Med Trop 2002; 35:661-663.

20. Correa MOA. Human leptospirosis in Brazil. Int J Zoonoses 1975; 2:1-9.

21. Pinheiro FP, Bensabath G, Andrade AHP, Lins ZC, Fraiha H, Tang AT, et al. Infectious diseases along Brazil's Trans-Amazon highway: surveillance and research. Bull Pan Am Health Org 1974; 8:111-122.

22. Santa Rosa CA, Lacaz CS, Machado PA, Yanaguita RM, Castrillón AL, Ferraroni JJ, et al. Leptospirose no Estado do Amazonas: inquérito sorológico. Rev Inst Med Trop São Paulo 1980; 22: 265-268.

23. Homem VSF, Heinemann MB, Moraes ZM, Vasconcellos SA, Ferreira F, Ferreira-Neto JS. Estudo epidemiológico da leptospirose bovina e humana na Amazônia oriental brasileira. Rev Soc Bras Med Trop 2001; 34:173-180.

24. Lins ZC, Lopes ML. Isolation of Leptospira from wild forest animals in Amazonian Brazil. Trans R Soc Tropical Med Hyg 1984; 78:124-126.

25. Saraiva MGG, Souza RS, Carvalho DL, Guerra MVF, Amorim RDS, Albuquerque BC. Leptospirose no município de Manaus: perfil dos casos registrados na Fundação de Medicina Tropical do Amazonas. Rev Soc Bras Med Trop 2004; 37:362.

26. Silva DX, Barcellos C, Bacuri R. Diagnóstico preliminar da vulnerabilidade e as previsões dos efeitos das mudanças climáticas na saúde pública no município de Manaus. Relatório preliminar do projeto "Guidance for Conducting Assessments of Health Vulnerability and Public Health and Health Care Interventions to Address Climate Change"; Manaus; 2010. p. 89.

27. Clemens SAC, Fonseca JC, Azevedo T, Cavalcanti A, Silveira TR, Castilho MC, et al. Soroprevalência para hepatite A e hepatite B em quatro centros no Brasil. Rev Soc Bras Med Trop 2000; 1:1-10.

28. Ministério da Saúde (Internet). Calendário nacional de vacinação (Cited 2012 May 20). Available at: http://www.blog.saude.gov.br/ index.php?tagTitle $=$ Vacina $\% \mathrm{C} 3 \% \mathrm{~A} 7 \% \mathrm{C} 3 \% \mathrm{~A} 3 \mathrm{o}$.

29. Villar LM, Paula VS, Gaspar AMC. Seasonal variation of hepatitis A virus infection in the City of Rio de Janeiro, Brazil. Rev Inst Med Trop São Paulo 2002; 44:289-292.

30. Pereira Fausto EL, Goncalves CS. Hepatite A. Rev Soc Bras Med Trop 2003; 36:387-400.

31. Braga WS, Borges FG, Barros Júnior GM, Martinho AC, Rodrigues IS, Azevedo EP, et al. Prevalence of hepatitis A virus infection: the paradoxical example of isolated communities in the western Brazilian Amazon region. Rev Soc Bras Med Trop 2009; 42:277-281.

32. Paula VS, Arruda ME, Vitral CL, Gaspar AM. Seroprevalence of viral hepatitis in riverine communities from the Western Region of the Brazilian Amazon Basin. Mem Inst Oswaldo Cruz 2001; 96:1123-1128.

33. Nunes HM, Soares MC, Silva HM. Hepatitis A virus infection in Amerindian area in the east Brazilian Amazon. Rev Soc Bras Med Trop 2004; 37:52-56.

34. Paula VS, Diniz-Mendes L, Villar LM, Luz SL, Silva LA, Jesus MS, et al. Hepatitis A virus in environmental water samples from the Amazon Basin. Water Res 2007; 41:1169-1176.

35. Paula VS, Niel C, Teves SC, Villar LM, Virgolino H, Gaspar AM. Molecular epidemiology of hepatitis A virus in Brazilian Amazon. J Gastroenterol Hepatol 2006; 21:1435-1438.

36. Alves AP, Moura DC, Spolti GP. Co-infection with hepatitis A and leptospirosis in the Amazon region: report of two cases. Trop Gastroenterol 2011; 32:234-236.

37. Costa OR. Incidência de parasitos intestinais em quatro cidades da Amazônia. Rev SESP 1947; 1:203-219.

38. Montenegro L. Incidência de protozoários e helmintos em Manaus. Rev Bras Med 1947; 4:266-268.

39. Deane MP. Helmintos eliminados por um grupo de residentes da Amazônia, após um tratamento pelo hexilresorcinol. Rev SESP 1950; 3:443-464.

40. Moraes MA. Investigation on intestinal parasites in the city of Codajas-State of Amazonas. Rev Bras Med 1959; 16:488-491.

41. Oliveira WR. Contribuição ao estudo coprológico na cidade de Manaus. Brasil Méd 1959; 73:123-125.

42. Pinheiro MFS, Vasconcelos JC, Wandel D. Contribuição ao estudo de parasitos intestinais em dois bairros de Manaus, Amazonas. Acta Amaz 1976; 6:67-73.

43. Pinheiro MFS, Marzochi MCA, Giugliano R, Giugliano LG. Enteroparasitoses em uma comunidade fechada. I - Estudo do solo como elo de transmissão em um orfanato de Manaus, Amazonas, Brasil. Acta Amaz 1977; 7:503-506.

44. Shrimpton R, Giugliano R. Nutrição em lactentes de um bairro de Manaus, Amazonas. Acta Amaz 1977; 7:247-253.

45. Montoril-Filho M, Ferraroni JJ, Montoril DAA. Diagnóstico sócioparasito-sanitário na cidade de Nova Olinda do Norte, Amazonas. Acta Amaz 1978; 8:91-98. 
46. Ferraroni MJ, Montoril-Filho M, Ferraroni, JJ. Parasitas intestinais numa população humana da cidade de Nova Olinda do Norte, Amazonas. Acta Amaz 1979; 9:657-659.

47. Dias LC, Dellome-Filho J, Paes MG, Farias AN, Aguiar JC. Prevalence of intestinal parasites in inhabitants of Rio Negro, State of Amazonas, Brazil. Acta Amaz 1982; 12:65-70.

48. Genaro O, Ferraroni JJ. Estudo sobre a malária e Parasitoses Intestinais em Indígenas da Tribo Nadëb-Maku, Estado do Amazonas, Brasil. Rev Saude Publica 1984; 18:162-169.

49. Giugliano R, Shrimpton R, Marinho HA, Giugliano LG. Estudos nutricionais das populações rurais da Amazônia. II. Rio Negro. Acta Amaz 1984; 14:427-449.

50. Ferraroni MJR, Marinho HA, Nagahama D, Silva NB, Castro J. Prevalencia de enteropatias na cidade de Manaus. J Pediatr 1991; 67:14-28.

51. Marinho HA, Shrimpton R, Giugliano R, Burini RC. Influence of enteral parasites on the blood vitamin A levels in preschool children orally supplemented with retinol and/or zinc. Eur J Clin Nutr 1991; 45:539-544.

52. Coura JR, Willcox HPF, Albuquerque BC, Lorenzi AG, Barroso DE, Lalama EME, et al. Aspectos epidemiológicos, sociais e sanitários em áreas do Médio Solimões. I. Estudo nas localidades de São Francisco do Laranjal, Aranaí e São Lázaro do Surubim, Município de Coari, Amazonas. An Acad Nac Med 1993; 153:122126.

53. Coura JR, Willcox HPF, Tavares AM, Castro JAF, Freitas ADA, Plasencia EP, et al. Aspectos epidemiológicos, sociais e sanitários em áreas do Médio Solimões. II. Estudo de dois bairros periféricos da cidade de Coari e quatro localidades do lago do Mamiá, Estado do Amazonas. An Acad Nac Med 1993; 153:183-186.

54. Rocha YR, Yuyama LKO, Nascimento OP. Perfil nutricional de pré-escolares e escolares residentes em Palmeiras do Javari, AM. Acta Amaz 1993; 23:9-14.

55. Coura JR, Willcox HPF, Tavares AM, Paiva DD, Fernandes O, Rada ELC, et al. Aspectos epidemiológicos, sociais e sanitários de uma área no Rio Negro, Estado do Amazonas, com especial referência às parasitoses intestinais e à infecção chagásica. Cad Saude Publica 1994; 10:327-336.

56. Martins M, Tavares AM. Prevalência de Parasitos Intestinais, Por Faixa Etária, Entre Indígenas Waimiri-Atroari no Amazonas, Brasil. Rev Soc Bras Med Trop 1995; 28 (supl I):112.

57. Martins M, Tavares AM. Controle de Parasitos Intestinais em Indígenas Waimiri-Atroari no Amazonas, Brasil. Rev Soc Bras Med Trop 1996; 29 (supl I):217.

58. Boia MN, Motta LP, Salazar MS, Mutis MPS, Coutinho RBA, Coura JR. Estudo das parasitoses intestinais e da infecção chagásica no município de Novo Airão, Estado do Amazonas, Brasil. Cad Saude Publica 1999; 15:497-504.

59. Martins M, Soares ARL, Moura MAS, Tavares A. Parasitoses intestinais no município de Novo Airão - AM. Rev Soc Bras Med Trop 2000; 33(supl I):149.

60. Tavares AM, Santos LO, Soares ARL, Calaça FC, Martins M. Parasitoses intestinais no Amazonas: Iranduba. Rev Soc Bras Med Trop 2001; 34 (supl I):305.

61. Chaves CC, Tavares AM, Soares ARL, Moura MAS, Soares AS, Chagas ECE, et al. Parasitoses intestinais em Codajás - AM. Rev Soc Bras Med Trop 2002; 35 (supl I):262.

62. Martins M, Alecrim W, Tavares AM, Soares ARL, Moura MAS, Chagas EC. Parasitoses intestinais na comunidade Nossa Senhora de Fátima, Manaus - AM. Rev Soc Bras Med Trop 2003; 36 (supl I):184.

63. Chagas ECS. Relação entre parasitismo intestinal e a variabilidade dos níveis de hemoglobina, eosinófilos, proteínas totais e estado nutricional na Comunidade Rural Nossa Senhora do Livramento, Manaus-AM. (Masters Dissertation). (Manaus): Fundação de Medicina Tropical do Amazonas, Universidade do Estado do Amazonas; 2004.

64. Tavares AM, Nascimento K, Castro IPS, Narezzi ML, Manoel S, Moreira R, et al. Parasitoses intestinais em população de Envira, Amazonas. Rev Soc Bras Med Trop 2004; 37 (supl I): 437.

65. Araújo CF, Fernández CL. Prevalência de parasitoses intestinais na cidade de Eirunepé, Amazonas. Rev Soc Bras Med Trop 2005; 38:69.

66. Benetton MLFN, Gonçalves AV, Meneghini MEF, Silva EF, Carneiro M. Risk factors for infection by the Entamoeba histolytica/E. dispar complex: an epidemiological study conducted in outpatient clinics in the city of Manaus, Amazon region, Brazil. Trans R Soc Trop Med Hyg 2005; 99:532-540.

67. Hurtado-Guerrero AF, Alencar FH, Hurtado-Guerrero JC. Ocorrência de enteroparasitas na população geronte de Nova Olinda do Norte - Amazonas, Brasil. Acta Amazônica 2005; 35:487-490.

68. Bóia MN, Costa CFA, Sodré FC, Silva WAE, Lamas CCL, Silva $\mathrm{MR}$, et al. Tratamento em massa para controle das helmintíases intestinais em área endêmica na Amazônia Brasileira. Rev Inst Med Trop Sao Paulo 2006; 48:189-195.

69. Franco SRNS. Incidência de parasitos intestinais em escolares de Lábrea, Amazonas, Brasil. Mem Inst Evandro Chagas 2006; 1:331336.

70. Martins M, Tavares AM. Levantamento epidemiológico de parasitos intestinais em amostras fecais da comunidade do PauRosa, Manaus-AM. Rev Soc Bras Med Trop 2006; 40 (supl I):183.

71. Oliveira AA, Nascimento AS, Santos TAM, Carmo GMI, Dimech $\mathrm{CPN}$, Alves RMS, et al. Estudo da prevalência e fatores associados à fasciolose no Município de Canutama, Estado do Amazonas, Brasil. Epidemiol Serv Saude 2007; 16:251-259.

72. Rios L, Cutolo SA, Giatti LL, Castro M, Rocha AA, Toledo RF, et al. Prevalência de parasitos intestinais e aspectos socioambientais em comunidade indígena no Distrito de Iauaretê, Município de São Gabriel da Cachoeira (AM), Brasil. Saúde Soc São Paulo 2007; 16:76-86.

73. Maia MMM, Fausto MA, Vieira ELM, Benetton MLFN, Carneiro M. The prevalence of malnutrition and its risk factors in children attending outpatient clinics in the City of Manaus Amazonas Brazil. Arch Latinoam Nutr 2008; 58:234-240.

74. Bóia MN, Carvalho-Costa FA, Sodré FC, Porras-Pedroza BE, Faria EC, Magalhães GAP, et al. Tuberculose e parasitismo intestinal em população indígena na Amazônia brasileira. Rev Saude Publica 2009; 43:176-178.

75. Monteiro AMC, Silva EF, Almeida KA, Sousa JJN, Mathias LA, Baptista F, et al. Parasitoses intestinais em crianças de creches públicas localizadas em bairros periféricos do município de Coari, Amazonas, Brasil. Rev Patol Trop 2009; 34:284-290.

76. Carvalho-Costa FA, Silva AG, Souza AH, Moreira CJC, Souza DL, Valverde JG, et al. Pseudoparasitism by Calodium hepaticum (syn. Capillaria hepatica; Hepaticola hepatica) in the Negro River, Brazilian Amazon. Trans R Soc Trop Med Hyg 2009; 103: 1071-1073.

77. Maia MM, Fausto MA, Vieira EL, Benetton ML, Carneiro M. Intestinal parasitic infection and associated risk factors, among children presenting at outpatient clinics in Manaus, Amazonas State, Brazil. Ann Trop Med Parasitol 2009; 103:583-591.

78. Silva EF, Silva EB, Almeida KS, Sousa JJN, Freitas FLC. Enteroparasitoses em crianças de áreas rurais do município de Coari, Amazonas, Brasil. Rev Patol Trop 2009; 38:35-43.

79. Melo GC, Reyes-Lecca RC, Vitor-Silva S, Monteiro WM, Martins $\mathrm{M}$, Benzecry SG, et al. Concurrent helminthic infection protects 
schoolchildren with Plasmodium vivax from anemia. PLoS One 2010; 5:e11206.

80. Santos FS, Gama ASM, Fernandes AB, Reis-Junior JDD, Guimarães J. Prevalência de enteroparasitismo em crianças de comunidades ribeirinhas do Município de Coari, no médio Solimões, Amazonas, Brasil. Rev Pan-Amaz Saude 2010; 1:23-28.

81. Oliveira CLM, Ferreira WA, Vasquez FG, Barbosa MGV. Parasitoses intestinais e fatores socioambientais de uma população da área Periurbana de Manaus- AM. Rev Bras Prom Saude 2010; 23:307-315.

82. Visser S, Giatti LL, Carvalho RA, Guerreiro JC. Study of the association between socio-environmental factors and the prevalence of intestinal parasitosis in the suburbs of the city of Manaus in the State of Amazonas, Brazil. Cien Saude Colet 2011; 16:3481-3492.

83. Silva EF, Silva VBC, Freitas FLC. Parasitoses intestinais em crianças residentes na comunidade ribeirinha São Francisco do Laranjal, município de Coari, Estado do Amazonas, Brasil. Rev Patol Trop 2012; 41:97-101.

84. Gonçalves AQ, Abellana R, Pereira-da-Silva HD, Santos I, Serra PT, Julião GR, et al. Comparison of the performance of two spontaneous sedimentation techniques for the diagnosis of human intestinal parasites in the absence of a gold standard. Acta Trop 2014; 131:63-70.

85. Fonseca JCF. Abscessos hepáticos. In: Parise ER, Porta G, editors. Manual de Diagnóstico e Tratamento das Doenças Hepáticas. São Paulo: Editora Francolor; 1999. p. 249-256.

86. Moraes LA. Estudo clínico de 104 casos de abscesso hepático amebiano do fígado no HJBB. Rev Bras Cir 1999; 227:54-60.

87. Salles JM, Moraes LA, Salles MC. Hepatic amebiasis. Braz J Infect Dis 2003; 7:96-110.

88. Ministério da Saúde(Internet). Plano Integrado de Ações Estratégicas de Eliminação da Hanseníase, Filariose, Esquistossomose e Oncocercose Como Problema de Saúde Pública, Tracoma Como Causa de Cegueira de Controle das Geohelmintíases - Plano de Ação 2011- 2015. (Cited May 20). Available at: http://bvsms.saude.gov.br/ bvs/publicacoes/plano_integrado_acoes_estrategicas_hanseniase. pdf.

89. World Health Organization (Internet). Water Quality and Health Strategy 2013-2020. (Cited May 20). Available at: http://www.who. int/water_sanitation_health/publications/2013/ water_quality_ strategy.pdf?ua $=1$ 